\title{
Polymorphonuclear leucocyte function and previous yersinia arthritis: enhanced chemokinetic migration and oxygen radical production correlate with the severity of the acute disease
}

\author{
PÄIVI KOIVURANTA-VAARA,${ }^{1 \cdot 2}$ MARJATTA LEIRISALO-REPO,$^{3}$ \\ AND HEIKKI REPO
}

From the Department of Bacteriology and Immunology, University of Helsinki; the ${ }^{2}$ Finnish Red Cross Blood Transfusion Service, Helsinki; and the ${ }^{3}$ Second Department of Medicine, Helsinki University Central Hospital, Finland

SUMmaRY Polymorphonuclear leucocyte (PMN) functions (migration in vitro, chemiluminescence, $\mathrm{O}_{2}^{-}$production, binding of chemotactic peptide, and aggregation) were studied in HLA-B27 positive patients with previous yersinia arthritis (YA). PMNs of patients whose disease had been severe showed chemokinetic and chemiluminescence responses significantly higher than the PMNs of those with a mild disease. The results support the view that enhanced PMN function contributes to inflammatory symptoms in patients with YA.

Key words: HLA-B27, chemotaxis, chemiluminescence, superoxide.

Both reactive arthritis, such as enteroarthritis following an infection caused by Yersinia enterocolitica, and ankylosing spondylitis are associated with the histocompatibility antigen HLA-B27. ${ }^{1}$ The mechanism of this association and the pathogenesis of the HLA-B27 linked diseases remain unknown, but exaggerated inflammatory responsiveness may be involved. ${ }^{2}$ This is supported by the findings that polymorphonuclear leucocytes (PMNs) of HLAB27 positive subjects, with or without yersinia arthritis (YA), and also those of patients with ankylosing spondylitis show higher chemotaxis in vitro than do PMNs of HLA-B27 negative healthy subjects. ${ }^{45}$ In addition, zymosan activated sera from HLA-B27 positive subjects stimulate PMN motility in vitro more than do such sera from HLA-B27 negative subjects. ${ }^{6}$ The relevance of these findings to the in vivo conditions has been confirmed by means of a skin chamber technique. ${ }^{7}$

To see whether a correlation can be found between enhanced PMN responsiveness and the severity of YA we compared PMN functions in two

Accepted for publication 22 September 1986.

Correspondence to Dr Päivi Koivuranta-Vaara, Department of Bacteriology and Immunology, University of Helsinki, Haartmaninkatu 3, SF-00290 Helsinki, Finland. groups (severe acute disease $v$ mild acute disease) of HLA-B27 positive patients with previous YA.

Patients and methods

PATIENTS

Twenty four HLA-B27 positive patients with previous YA from a follow up study ${ }^{8}$ were assigned to two groups on the basis of their clinical characteristics during the acute phase of the disease (Table 1). The mean intervals between the acute phase of YA and the time of the present study were 8.5 years (range 5-14) in group I and 8.6 years (5-11) in group II. Two patients, one in each group, were studied simultaneously, and the pairs were matched for age and sex (three pairs were matched only for age). At the time of the present study one patient in each group was taking indomethacin (75-100 mg/day), the others were free of symptoms and signs of active disease.

CELLS

Buffy coat cells for the migration assays were separated from heparinised venous blood by dextran sedimentation. PMNs (95-99\% pure) for other assays were separated from the buffy coat cells by 
Table 1 Clinical characteristics of the patients in group I (severe acute phase) and group II (mild acute phase) during the acute phase of yersinia arthritist

\begin{tabular}{|c|c|c|}
\hline & Group If & Group II \\
\hline Number of patients & 12 & 12 \\
\hline Sex: men/women & $6 / 6$ & $5 / 7$ \\
\hline Age in years at the onset of the disease, mean (range) & $30 \cdot 2(17-45)$ & $33 \cdot 7(22-54)$ \\
\hline Number of involved joints, mean (range) & $7 \cdot 1(1-15)$ & $4 \cdot 2(2-13)$ \\
\hline Duration of symptoms in months, mean (range) & $5 \cdot 0(2-12)$ & $3 \cdot 2(1-5)$ \\
\hline \multicolumn{3}{|l|}{ Laboratory findings } \\
\hline $\begin{array}{l}\text { Yersinia enterocolitica agglutinins, geometric mean (range)§ } \\
\text { Highest erythrocyte sedimentation rate, }\end{array}$ & $2148(160-10240)$ & $1328(320-10240)$ \\
\hline $\mathrm{mm} / \mathrm{h}$, mean (range) & $101(41-148)^{*}$ & $54(16-80)$ \\
\hline Highest white blood cell count, $10 \cdot 0 \times 10^{9} / 1$, mean (range) & $12 \cdot 4(10 \cdot 8-16 \cdot 5)^{* *}$ & $7 \cdot 6(6 \cdot 2-10 \cdot 9)$ \\
\hline \multicolumn{3}{|l|}{ Extra-articular symptoms } \\
\hline Total number of patients affected & $9^{*}$ & 3 \\
\hline Iritis/conjunctivitis & 5 & 1 \\
\hline Balanitis/pyuria & 6 & 2 \\
\hline Keratoderma blenorrhagica & 1 & - \\
\hline Erythema nodosum & - & 1 \\
\hline
\end{tabular}

†The patients in group I showed at least two, and the patients in group II only one (or none) of the following clinical characteristics: ( $\overrightarrow{\mathscr{A}}$ highest erythrocyte sedimentation rate $\geqslant 110 \mathrm{~mm} / \mathrm{h} ;(b)$ highest white blood cell count $\geqslant 10 \cdot 0 \times 10^{9} / \mathrm{l} ;(c)$ presence of extra-articulat manifestations.

$\ddagger$ The significance of the difference between the two groups is indicated as follows: ${ }^{*} p<0 \cdot 005,{ }^{* *} p<0 \cdot 001$.

§Maximal Yersinia enterocolitica agglutinins expressed as reciprocals of dilutions.

density gradient centrifugation ${ }^{9}$ followed by hypotonic lysis of the erythrocytes.

NEUTROPHIL STIMULATING AGENTS Zymosan activated serum (ZAS) was prepared from pooled normal human serum (NHS) as previously described. ${ }^{10} \mathrm{~N}$-Formyl-methionyl-leucylphenylalanine (fMLP) was purchased from Sigma Chemical Co, St Louis, Missouri. For opsonisation, $20 \mathrm{mg}$ of zymosan particles (Sigma) in $1 \mathrm{ml}$ of NHS were incubated at $37^{\circ} \mathrm{C}$ for $30 \mathrm{~min}$, washed twice, and resuspended in $1.4 \mathrm{ml}$ of phosphate buffered saline (PBS).

MEMBRANE FILTER ASSAY

The leading front modification ${ }^{11}$ of the Boyden chamber technique ${ }^{12}$ was applied according to Wilkinson. ${ }^{13}$ The attractants and reference solutions were used above and below the filters as follows: HBSS/HBSS (Hanks's balanced salt solution) in studies of spontaneous locomotion, $0 \cdot 2 \%$ HSA/ $0.2 \%$ HSA (human serum albumin, AB Kabi, Stockholm, Sweden), $10^{-8} \mathrm{M}$ fMLP $/ 10^{-8} \mathrm{M}$ fMLP, $10^{-9} \mathrm{M}$ fMLP $/ 10^{-9} \mathrm{M}$ fMLP, and $12 \% \mathrm{ZAS} / 12 \%$ ZAS in studies of chemokinesis, and $0 \cdot 2 \% \mathrm{HSA} / 10^{-8}$ $\mathrm{M}$ fMLP, and $3 \% \mathrm{ZAS} / 12 \% \mathrm{ZAS}$ in studies of chemotaxis. All fMLP dilutions were made in HBSS containing $0 \cdot 2 \%$ HSA. The filters were incubated for $45 \mathrm{~min}$ at $37^{\circ} \mathrm{C}$. The coefficient of variation was $2-18 \%$.
AGAROSE ASSAY

PMN migration under agarose was determined $\frac{\supset}{\mathrm{a}}$ described earlier. ${ }^{10}$ In studies of spontaneou๊ locomotion the agarose medium contained $0.2 \%$ HSA. In studies of chemokinesis and chemotaxis th $\overrightarrow{\mathrm{F}^{*}}$ attractants were $10^{-8} \mathrm{M}$ and $10^{-9} \mathrm{M}$ fMLP and $12 \%$ ZAS, and $5 \times 10^{-7} \mathrm{M}$ fMLP and ZAS respectivelye The coefficient of variation was $5-20 \%$.

CHEMILUMINESCENCE ASSAY

PMNs $\left(2.0 \times 10^{6}\right)$ in $100 \mu$ l of PBS were kept at $37^{\circ} \stackrel{\circ}{\circ}$ for one minute and mixed with $100 \mu \mathrm{l}$ of $10^{-5} \mathrm{M} \mathrm{fMLP्}$ or $100 \mu \mathrm{l}$ of zymosan particles, and with $200 \mu \mathrm{l}$ of the luminol solution $(10 \mu \mathrm{g} / \mathrm{ml}$ in PBS; Fluka AG, Buchs SG, Switzerland). The recording periods wer8 $8 \mathrm{~min}$ for fMLP and $13 \mathrm{~min}$ for zymosan. Both the area under the chemiluminescence curve $\left(\mathrm{cm}^{2}\right)$ and. the height of the curve as millivolts $(\mathrm{mV})$ at onfer minute intervals were determined.

\section{$\mathrm{O}_{2}^{-}$PRODUCTION ASSAY}

The method of Pick and Mizel $^{14}$ was used ds described ${ }^{15}$ to determine $\mathrm{O}_{2}^{-}$production of PMN fMLP $\left(10^{-6}, 10^{-7}\right.$, and $\left.10^{-8} \mathrm{M}\right)$ was used as th $\Phi$ stimulus. Incubation periods were 15,30 , and $60 \mathrm{~min}$. The coefficient of variation was $7-25 \% \overline{0}$

f-Met-Leu- $\left({ }^{3}\right.$ H ) Phe BINDING ASSAY

Binding was assayed largely as described by Wi令 liams et al. ${ }^{16}$ Fifty microlitres of f-Met-Leu- $\left({ }^{3} \mathrm{H}\right) \mathrm{PhE}$ (New England Nuclear, Boston, Massachusettso 
specific activity $48.3 \mathrm{Ci} / \mathrm{mmol}(1.787 \mathrm{TBq} / \mathrm{mmol}))$ in $30,60,120,160 \mathrm{nM}$ concentrations, $50 \mu \mathrm{l}$ of unlabelled fMLP $(240 \mu \mathrm{M})$, or incubation buffer, ${ }^{16}$ and $50 \mu \mathrm{l}$ of PMNs $\left(90.0 \times 10^{6} / \mathrm{ml}\right)$ were incubated at $37^{\circ} \mathrm{C}$ for $12 \mathrm{~min}$. Ice cold buffer $(2 \mathrm{ml})$ was added, and the suspensions rapidly filtered through glass fibre filters (Gelman Sciences Inc, Ann Arbor, Michigan). The filters were washed with $10 \mathrm{ml}$ of ice cold buffer, dried, and their radioactivity measured. Specific binding in duplicate filters was calculated by subtracting the non-specific binding (the amount of binding not inhibited by $80 \mu \mathrm{M}$ unlabelled fMLP) from the total binding of radiolabelled $\mathrm{MLP}$, and expressed as $\mathrm{fmol} / 10^{6}$ PMNs. The coefficient of variation was $1-20 \%$.

\section{A GGREGATION ASSAY}

A standard platelet aggregometer (Payton Associates, Buffalo, New York) was applied as described by Craddock. ${ }^{17}$ Light transmission limits were calibrated with cell suspensions $\left(10.0 \times 10^{6}\right.$ and $5.0 \times 10^{6}$ PMNs $/ \mathrm{ml}$ ) of each patient. An aliquot of $0.3 \mathrm{ml}$ of the PMN suspension $\left(10.0 \times 10^{6} / \mathrm{ml}\right)$ was added to a siliconised cuvette containing a siliconised stirring

Table 2 The mean distances of spontaneous, chemokinetic, and chemotactic migration in two groups of HLA-B27 positive patients with previous yersinia arthritis. Group I: severe acute phase, group II: mild acute phase

\begin{tabular}{|c|c|c|}
\hline & \multicolumn{2}{|c|}{ Distance of migration $\ddagger$} \\
\hline & Group I & Group II \\
\hline Membrane filter assay ${ }^{\dagger}$ & \multicolumn{2}{|c|}{$(\mu m$, mean $(S D))$} \\
\hline Spontaneous locomotion & $18(3)$ & $17(2)$ \\
\hline \multicolumn{3}{|l|}{ Chemokinesis: } \\
\hline $0.2 \%$ HSA & $51(5)$ & $51(8)$ \\
\hline $12 \%$ ZAS $\S$ & $75(16)^{* *}$ & $61(12)$ \\
\hline $10^{-x} \mathrm{M}$ fMLP & $52(11)$ & 54 (13) \\
\hline $10^{-9} \mathrm{M}$ fMLP & $54(11)$ & $50(12)$ \\
\hline \multicolumn{3}{|l|}{ Chemotaxis: } \\
\hline $12 \%$ ZAS & $62(9)$ & $58(10)$ \\
\hline $10^{-x} \mathrm{M}$ fMLP & 61 (13) & $64(18)$ \\
\hline Agarose assay ${ }^{\dagger}$ & \multicolumn{2}{|c|}{$(m m$, mean $(S D))$} \\
\hline Spontaneous locomotion & $1.0(0.3)$ & $0.9(0.3)$ \\
\hline \multicolumn{3}{|l|}{ Chemokinesis: } \\
\hline $12 \%$ ZAS & $1.4(0.3)$ & $1.4(0.4)$ \\
\hline $10^{-8} \mathrm{M}$ fMLP§ & $3 \cdot 1(0 \cdot 6)^{*}$ & $2.9(0.7)$ \\
\hline $10^{-9} \mathrm{M}$ fMLP & $1.8(0.6)$ & $1.7(0.6)$ \\
\hline \multicolumn{3}{|l|}{ Chemotaxis: } \\
\hline ZAS & $2 \cdot 0(0 \cdot 5)$ & $1.9(0.4)$ \\
\hline $5 \times 10^{-7} \mathrm{M}$ fMLP & $3.3(0.4)$ & $3 \cdot 1(0 \cdot 6)$ \\
\hline
\end{tabular}

†Abbreviations: HSA=human serum albumin; ZAS=zymosan activated serum; $\mathrm{fMLP}=\boldsymbol{N}$-formyl-methionyl-leucyl-phenylalanine. $¥$ The significance of the difference between the two groups (paired sample $t$ test) is indicated as follows: ${ }^{*} \mathrm{p}<0.05,{ }^{* *} \mathrm{p}<0.01$.

$\S$ Detailed data are presented in Fig. 1. bar $(900 \mathrm{rpm})$. After two minutes $5 \mu$ of fMLP $\left(10^{-5} \mathrm{M}\right)$ or HBSS was added, and the changes in light transmission were recorded for five minutes. Both the area $\left(\mathrm{cm}^{2}\right)$ under the curve and the maximal change $(\mathrm{cm})$ in light transmission were determined. All experiments were done in duplicate. The coefficient of variation was $1-10 \%$.

\section{STATISTICAL METHODS}

Comparisons of the clinical characteristics between the two groups were performed with Student's $t$ test (age, laboratory findings; geometric means were used in comparing Yersinia enterocolitica agglutinin titres), $\chi^{2}$ test with Yates's correction (sex distribution, extra-articular manifestations), KolmogorovSmirnov test (duration of symptoms), or Wilcoxon rank sum test (number of involved joints). In all other comparisons the paired sample $t$ test was used.

\section{Results}

\section{G R A T I O N}

In the membrane filter assay the group I PMNs showed significantly higher chemokinetic migration in ZAS than did the group II PMNs (Table 2, Fig. 1A). Also the chemotactic migration towards ZAS was higher in group I, but the difference was not significant $(\mathrm{p}<0 \cdot 10)$. No clear differences were found
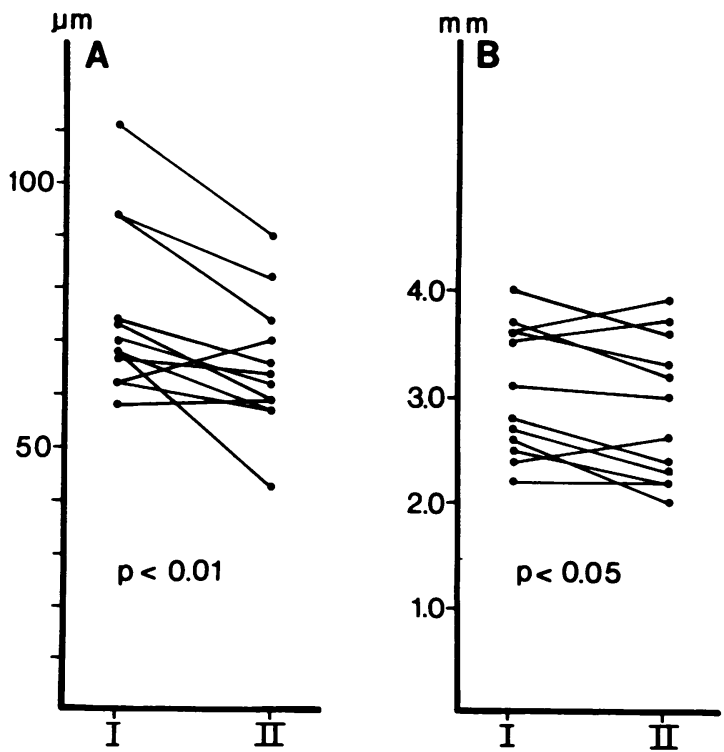

Fig. 1 Chemokinetic migration of PMNs (I, severe acute phase; II, mild acute phase). (A) $12 \% Z A S$ in the membrane filter assay; (B) $10^{-8} M$ fMLP in the agarose assay. 
in spontaneous locomotion (in HBSS), chemokinetic locomotion (in HSA or fMLP), or chemotactic locomotion induced by fMLP (Table 2).

In the agarose assay the group I PMNs showed higher chemokinetic migration in IMLP at the optimal $10^{-8} \mathrm{M}$ concentration (Table 2, Fig. 1B). Chemotactic migration towards fMLP was higher in nine out of 12 pairs, but the difference was not statistically significant. No major differences were found in spontaneous locomotion, or chemokinetic or chemotactic locomotion induced by ZAS (Table 2).

We also tested the patients' sera for their ability to stimulate chemokinetic locomotion of the cells of one healthy blood donor by means of the membrane filter assay. No significant differences were found between the two groups tested in parallel using fresh sera, heated $\left(56^{\circ} \mathrm{C}, 30 \mathrm{~min}\right)$ sera, ZAS, and heated ZAS (data not shown).
CHEM I LUM INES CENCE

The shape of the curves was the same in both? groups, with a single peak 1-2 min or 5-7 min afte adding fMLP or zymosan respectively (Fig. 2). That only one peak was found with fMLP was probably because the cells had been kept at room temperw ature for two to three hours before testing. ${ }^{18}$ The group I PMNs tended to display higher responses te both zymosan and fMLP (Fig. 2). In studies witl? zymosan the mean areas (SD) under the curves an $\vec{P}$ the mean heights (SD) of the maximal responses in groups I and II were $52.5(18.0)$ and $44.1(16.9) \mathrm{cm}$ (Fig. 3A) and 131 (52) and 105 (38) mV respect ively. The differences between the two groups wer发 not statistically significant. In studies with fMLP the areas under the curves were significantly larger id group I than in group II ( $\mathrm{p}<0.02$, Fig. 3B), the mea areas being $43.0(15.1) v 30.0(11.7) \mathrm{cm}^{2}$. The meat

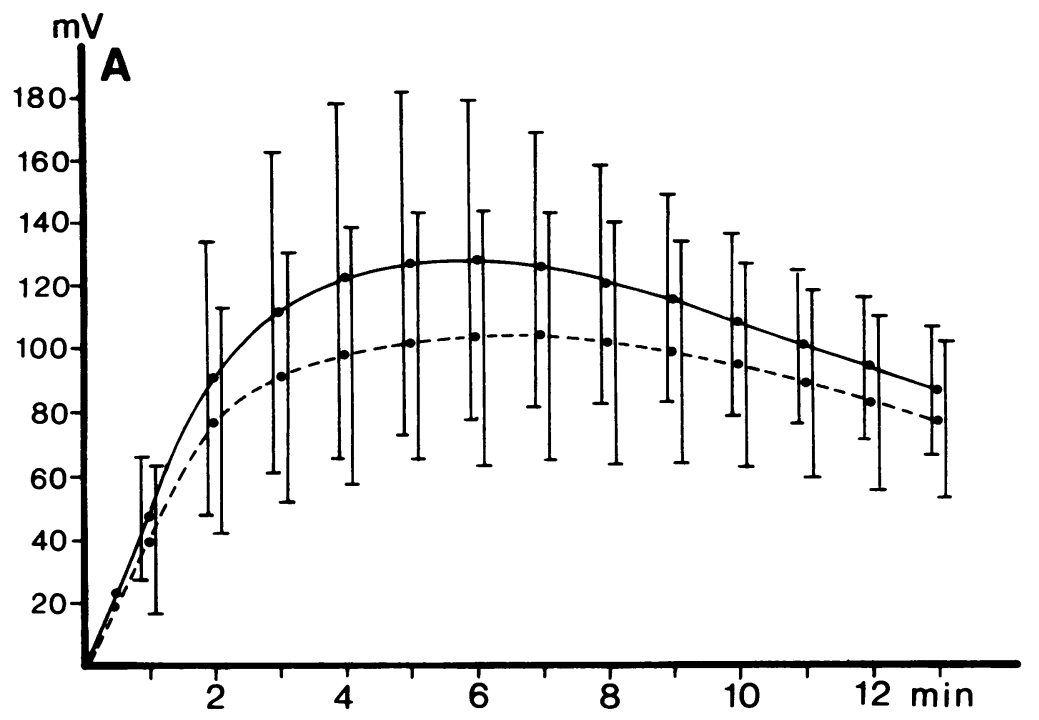

Fig. 2 Chemiluminescence responses of PMNs to $(A)$ zymosan and $(B) f M L P$. The curves are drawn through points representing the mean response of the whole group $(n=12$ in $A ; n=17$ in B) at each time point. Solid ling severe acute phase (group I); dashed line, mild acute phase (group II).

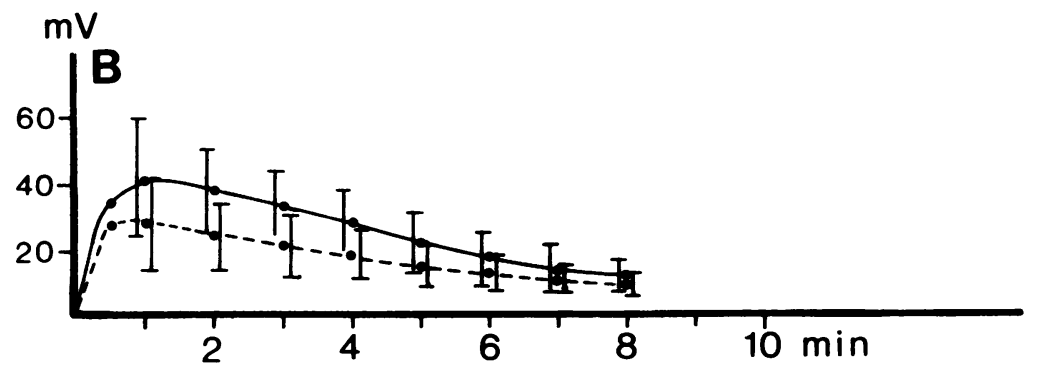



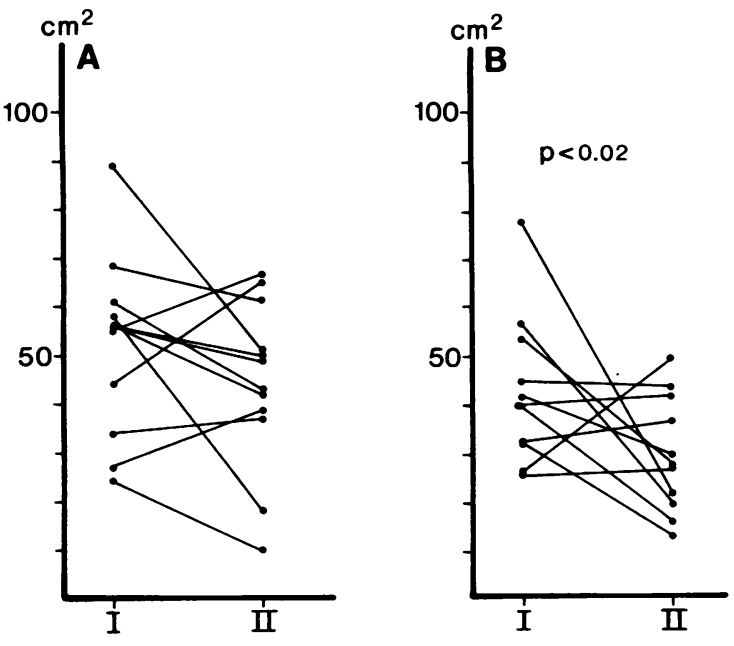

the two groups, the mean (SD) responses in groups

I and II being $24.2(3.9)$ and $25.7(5.7) \mathrm{cm}$, and $28 \cdot 2(5 \cdot 0)$ and $28.6(6 \cdot 4) \mathrm{cm}^{2}$ respectively.

Fig. 3 Chemiluminescence responses (areas under the curves) of PMNs to (A) zymosan and (B) $f M L P$. I, severe acute phase; II, mild acute phase. In one patient the response to $F M L P$ could not be studied because of a low yield of PMNs.

heights of the maximal responses to fMLP were 44 (20) and 31 (18) $\mathrm{mV}$ in groups I and II respectively (not statistically significant).

PRODUCTION OF $\mathrm{O}_{2}^{-}$

The maximum response was achieved with $10^{-6} \mathrm{M}$ fMLP during a one hour incubation. There were no statistically significant differences between groups I and II in the maximal responses (mean (SD): 41.1 (26.2) v $50.6(25.9) \mathrm{nmol} / \mathrm{mg}$ of PMN protein respectively), or in the responses recorded with any fMLP concentration at any time point.

\section{f-Met-Leu- $\left({ }^{3} \mathrm{H}\right)$ Phe B IN DING}

The binding reached a plateau between $40 \mathrm{nM}$ and $80 \mathrm{nM}$ fMLP. The amount of f-Met-Leu- $\left({ }^{3} \mathrm{H}\right)$ Phe bound at $80 \mathrm{nM}$ was considered to represent the total binding capacity. The PMNs of group I bound somewhat more radiolabelled fMLP (mean (SD): 108 (35) fmol $/ 10^{6}$ PMNs) than group II PMNs (89 (27)), but the difference was not statistically significant (Fig. 4).

\section{A G G R E G A T I O N}

The tracings of the aggregation responses to $10^{-5} \mathrm{M}$ fMLP were of uniform shape in both groups. They reached a peak in one to two minutes and showed slow disaggregation thereafter. Neither the maximal responses (Fig. 5) nor the areas under the curves showed statistically significant differences between

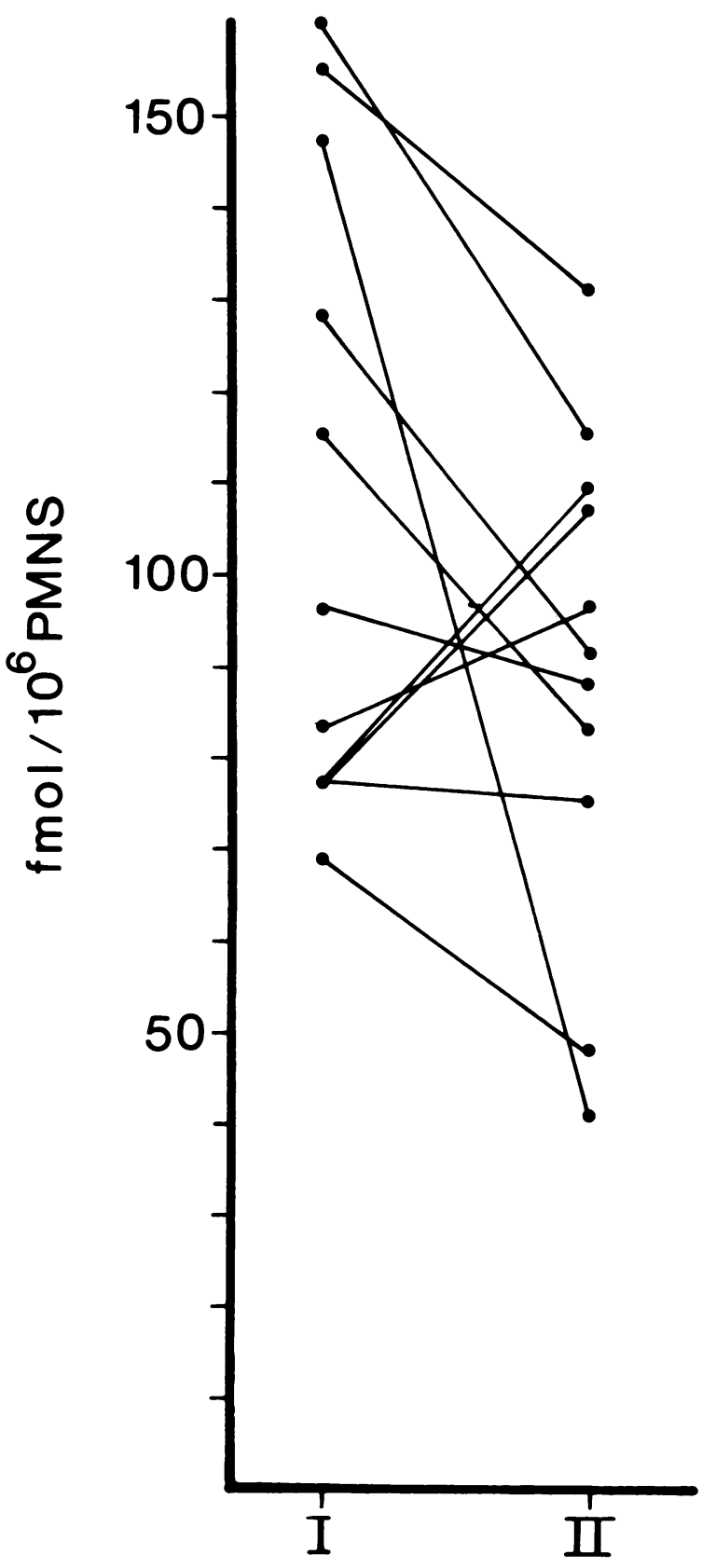

Fig. 4 Specific binding of $80 \mathrm{nM}$-Met-Leu- $\left({ }^{3} \mathrm{H}\right)$ Phe by PMNs. I, severe acute phase; II, mild acute phase. In one patient, binding could not be studied because of a low yield of PMNs. 


\section{Discussion}

We have studied several parameters of PMN function in two groups of HLA-B27 positive patients

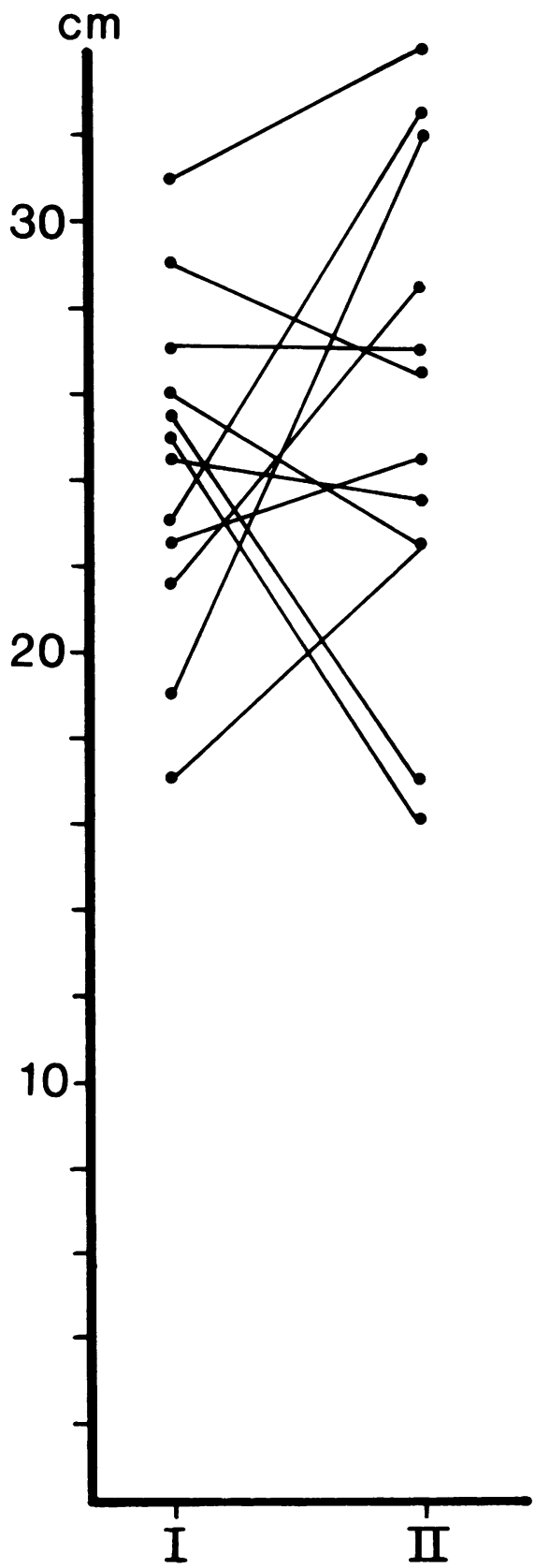

Fig. 5 Maximum aggregation responses of PMNs. I, severe acute phase; II, mild acute phase. with previous YA. The results indicate that bot: migratory and oxygen radical producing capacities: of PMNs from patients who had had severe Y $\overrightarrow{s e}$ (high erythrocyte sedimentation rate, high white blood cell count, high prevalence of extra-articulaw manifestations) were higher than in patients whose disease had been mild.

To migrate under agarose PMNs may have to deform less than in the filter, ${ }^{19}$ and their distances of migration are 50 - to 100 -fold greater. We therefore used the two assays in parallel. Group I PMNs showed enhanced chemokinesis both under agaros $\omega$ and in filter, though towards different attractant The reason for the discrepancy is not known, but may involve differences in the character of the tw methods.

In the chemiluminescence assay the group I PMN tended to display higher responses to both zymosam and fMLP, whereas spectrophotometric assessment. of $\mathrm{O}_{2}^{-}$production showed no differences between thes groups. The latter technique, however, detects onl reduction of cytochrome $c$ sensitive to superoxide dismutase, whereas in the chemiluminescence assa combined actions of $\mathrm{O}_{2}^{-}$, hydrogen peroxide, and myeloperoxidase on the oxidation of luminol can bह measured. ${ }^{20}$

The capacity of the cells to bind radiolabelle fMLP can be taken as an estimate of the amount fMLP receptors on the PMNs. The group I new trophils bound slightly more fMLP than the group cells.

We found no difference between the two groups in the aggregation assay, which measures the adhe $\vec{p}$. ence of PMNs to each other. PMN aggregation and adhesion to surfaces, however, may be separate ce functions, ${ }^{21}{ }^{22}$ and it might be interesting to coms pare the groups using an assay measuring the adherence of PMNs to surfaces, such as endothelia cell monolayers.

In conclusion, the results show that among HLA B27 positive patients the severity of the acute Y correlates with enhanced PMN function. The intee. val between the acute phase of the disease and the present study was five to 14 years, and thus the cels seem to retain their high responsiveness even in the absence of clinically active disease. At present cannot be concluded with certainty whether the higi PMN responsiveness is genetically determined of secondarily acquired. Still, the exaggerated PME function may contribute to inflammatory tissue injury in $\mathrm{YA}^{3}$ and, evidently, also in other HLA B27 associated diseases such as ankylosing spondylitis. ${ }^{23}$ It remains to be seen whether the long term prognosis of the patients with enhanced PMA function (group $I$ in the present study) is differey from that of group II patients. 
We thank Ms Eine Virolainen for skilful technical assistance, and Ms Sisko Asp (M Pol Sc) for advice on statistical analysis. This study was supported by grants from Tamro-Star Medical Research Foundation and from the Academy of Finland.

\section{References}

1 Brewerton D A. HLA-B27 and the inheritance of susceptibility to rheumatic disease. Arthritis Rheum 1976; 19: 656-68.

2 Rosenbaum J T. Why HLA-B27: an analysis of two animal models. Ann Intern Med 1981; 94: 261-3.

3 Repo H, Leirisalo M, Koivuranta P, et al. Neutrophil function and HLA-B27. Br J Rheumatol 1983; 22 (suppl 2): 168-71.

4 Leirisalo M, Repo H, Tiilikainen A, Kosunen T U, Laitinen O. Chemotaxis in yersinia arthritis. HLA-B27 positive neutrophils show high stimulated motility in vitro. Arthritis Rheum 1980; 23: 1036-44.

5 Pease C T, Fordham J N, Currey H L F. Polymorphonuclear cell motility, ankylosing spondylitis, and HLA-B27. Ann Rheum Dis 1984; 43: 279-84.

6 Repo H, Leirisalo M, Tiilikainen A, Laitinen O. Chemotaxis in yersinia arthritis. In vitro stimulation of neutrophil migration by HLA-B27 positive and negative sera. Arthritis Rheum 1982; 25: 655-61.

7 Koivuranta-Vaara P, Repo H, Leirisalo M, Kiistala U, Österman T, Vapaatalo $H$. Enhanced neutrophil migration in vivo in HLA-B27 positive subjects. Ann Rheum Dis 1984; 43: 181-5.

8 Leirisalo M, Skylv G, Kousa M, et al. Follow up study on patients with Reiter's disease and reactive arthritis, with special reference to HLA-B27. Arthritis Rheum 1982; 25: 249-59.

9 Boyum A. Separation of blood leukocytes, granulocytes and lymphocytes. Tissue Antigens 1974; 4: 269-74.

10 Repo H, Kosunen TU. Leukocyte migration agarose test for the assessment of human neutrophil chemotaxis. II. Variables in the attraction assay. Scand J Immunol 1977; 6: 211-8.

11 Zigmond S H, Hirsch J G. Leukocyte locomotion and chemotaxis: new methods of evaluation, and demonstration of a cellderived chemotactic factor. $J$ Exp Med 1973; 137: 387-410.
12 Boyden S. The chemotactic effect of mixtures of antibody and antigen on polymorphonuclear leucocytes. J Exp Med 1962; 115: 453-66.

13 Wilkinson P C. Chemotaxis and inflammation. Edinburgh: Churchill Livingstone, 1974: 168-72.

14 Pick E, Mizel D. Rapid microassays for the measurement of superoxide and hydrogen peroxide production by macrophages in culture using an automatic enzyme immunoassay reader. J Immunol Methods 1981; 46: 211-26.

15 Repo H, Leirisalo-Repo M, Skurnik M, Tiilikainen A. Neutrophil function and HLA-B27. Superoxide production and yersinocidal activity of neutrophils from patients with previous yersinia arthritis. Med Biol 1984; 62: 91-4.

16 Williams L T, Snyderman R, Pike M C, Lefkowitz R J. Specific receptor sites for chemotactic peptides on human polymorphonuclear leucocytes. Proc Natl Acad Sci USA 1977; 74: 1204-8.

17 Craddock P R. Granulocyte aggregometry. In: Douglas S D, Quie $P$ G, eds. Investigation of phagocytes in disease. London: Churchill Livingstone, 1981: 3-11.

18 Dahlgren C, Stendahl O. Effect of in vitro preincubation of polymorphonuclear leukocytes on formyl-methionyl-leucylphenylalanine induced chemiluminescence. Infect Immun 1982; 37: 34-9.

19 Repo H, Jokipii A M M, Leirisalo M, Kosunen T U. Leucocyte motility in the newborn: determination of spontaneous movement is essential in the in vitro assessment of neutrophil chemotaxis. Clin Exp Immunol 1980; 40: 620-6.

20 Bender J G, Van Epps D E. Analysis of the bimodal chemiluminescence pattern stimulated in human neutrophils by chemotactic factors. Infect Immun 1983; 41: 1062-70.

21 Dahinden C, Fehr J. Granulocyte activation by endotoxin. II. Role of granulocyte adherence, aggregation, and effect of cytochalasin B, and comparison with formylated chemotactic peptide-induced stimulation. J Immunol 1983; 130: 863-8.

22 Harlan J M. Leukocyte endothelial interactions. Blood 1985; 65: 513-25.

23 McGuigan L E, Geczy A F, Edmonds J P. The immunopathology of ankylosing spondylitis: a review. Semin Arthritis Rheum 1985; 15: 81-105. 